\title{
Correlation Between Hepatitis B G1896A Precore Mutations and HBeAg in Chronic HBV Patients
}

\author{
Sareh Zhand ${ }^{1}$; Chiman Karami ${ }^{1}$; Ahmad Hosseinzadeh Adli ${ }^{1}$; Alijan Tabarraei ${ }^{1}$; Behnaz \\ Khodabakhshi ${ }^{2}$; Abdolvahab Moradi ${ }^{1,}$ \\ ${ }^{1}$ Department of Microbiology, School of Medicine, Golestan University of Medical Sciences, Gorgan, IR Iran \\ 2 Infectious Diseases Research Centre, Golestan University of Medical Sciences, Gorgan, IR Iran \\ ${ }^{*}$ Corresponding author: Abdolvahab Moradi, Department of Microbiology, School of Medicine, Golestan University of Medical Sciences, Gorgan, IR Iran. Tel: +98-9111772107, Fax: \\ +98-1714440225, E-mail: abmoradi@yahoo.com
}

Received: December 29, 2013; Revised: July 14, 2014; Accepted: September 27, 2014

\begin{abstract}
Background: Hepatitis B virus (HBV) infection is an important health concern worldwide, with critical outcomes. Hepatitis B e antigen (HBeAg) negative chronic hepatitis B is frequently caused by a mutation (G1896A) in the hepatitis B virus (HBV) precore (PC) reading frame, which creates a stop codon, causing premature termination of the HBe protein.

Objectives: This study aimed to investigate the G1896A PC mutation and its effect on HBeAg detection in chronic HBV patients.

Patients and Methods: In this study, 120 chronic HBV patients neither vaccinated or who had benefited from immunoglobulin therapy, were recruited. The HBV-DNA was extracted from plasma and polymerase chain reaction (PCR) was performed. Positive PCR products were subjected to automated sequencing. The HBV serological markers [hepatitis B s antigen (HBsAg), HBeAg] were tested.

Results: One hundred out of 120 (83.3\%) patients were HBeAg negative and 100\% were HBsAg positive. The comparison of nucleotide sequences with the reference sequence (Accession number: AB033559) in HBeAg negative patients showed that there was a high rate of mutations in G1896A (93.18\%).

Conclusions: This study indicates that the rate of G1896A mutation at the PC region among HBeAg negative patients, in the Golestan province of Iran, was similar to the average rate encountered in other parts of Iran. The PC stop codon mutation was detected in $93.18 \%$ of HBeAg negative patients. Further studies with larger sample sizes are required to elucidate the exact role of these mutations in the clinical course of chronic HBV infection.
\end{abstract}

Keywords:Hepatitis B, Chronic; Mutation; Hepatitis B e Antigens; Iran

\section{Background}

Hepatitis B Virus (HBV) infection is an important health concern worldwide, with critical outcomes (1). It is a well-known agent of acute and chronic hepatitis, liver cirrhosis and hepatocellular carcinoma. Chronic HBV infection, defined by the persistence of the surface antigen (HBsAg) in the serum for longer than six months, may lead to a wide spectrum of liver disease (2). Hepatitis B e antigen (HBeAg) is considered a marker for viral replication, whereas the presence of anti-HBe antibodies often indicates a low level of viral replication. In the natural course of chronic HBV infection, the loss of HBeAg expression and the appearance of antibodies directed against it (Anti-HBe) are usually accompanied by cessation of viral replication. However, such a serology profile may also be seen in individuals who harbor precore (PC) and basal core promoter (BCP) mutants, where replicative infection continues.

The most common of these mutations is a guanine $(G)$ to adenine (A) substitution at nucleotide1896, which prevents the production of HBeAg by introducing a pre- mature stop codon into the open reading frame (ORF) of the PC. Mutations in the PC region of the HBV genome have been reported in multiple HBeAg-negative patients with chronic HBV infection. The predominant mutation involves a GtoA change at nucleotide1896 (A1896), which creates a premature stop codon at codon 28. This mutation prevents the translation of the HBeAg and completely abolishes the production of HBeAg (3). Besides the A1896 mutation, a number of point mutations leading to initiation failure or premature termination, as well as deletions and insertions of nucleotides inducing frame shifts, have been detected in the precore region (2).

Precore mutants are more common among patients with genotype D (65-75\%) than genotype A (9-18\%)(4). However, this mutation is located within the epsilon $(\varepsilon)$ structure, a highly conserved stem-loop essential for the initiation of encapsidation within the viral replication cycle. In order to stabilize the $\varepsilon$ structure, the nucleotide at position 1896 is paired with the nucleotide at position 1858 , which naturally is a thymidine $(\mathrm{T})$ in genotypes $\mathrm{B}$,

Copyright (C) 2015, Ahvaz Jundishapur University of Medical Sciences. This is an open-access article distributed under the terms of the Creative Commons Attribution-NonCommercial 4.0 International License (http://creativecommons.org/licenses/by-nc/4.0/) which permits copy and redistribute the material just in noncommercial usages, provided the original work is properly cited. 
$\mathrm{D}, \mathrm{E}$, and $\mathrm{G}$ and a cytosine (C) in genotype A (5). Infection with the precore A1896 mutant virus is often accompanied by the presence of mutations in the core region. Novel core variants may emerge de novo during the course of the disease, or may circulate as a mixture of quasi species. Since the core protein is a known target of $\mathrm{B}$ - and T-cell responses, the altered core antigenicity may help the virus to escape immune recognition and lead to virus persistence (6). Iran is considered as a country with low endemicity of chronic HBV infection (7). Our previous study in Golestan province showed a higher prevalence of HBV infection and HBV S gene mutation compared to other parts of Iran $(8,9)$.

\section{Objectives}

In this study, the G1896A precore mutation and its effect on HBeAg detection were investigated in chronic HBV patients, using polymerase chain reaction (PCR) and subsequent sequencing method, rather than the restriction fragment length polymorphism (RFLP), because of improving the sensitivity of the detection.

\section{Patients and Methods}

\subsection{Sample Selection}

One hundred and twenty patients with proved chronic HBV infection, according to clinical and paraclinical evidence, with HBsAg testing positive for more than 6 months, who have been referred by specialists for HBV infection diagnosis and viral load test to virology diagnostic laboratory of Golestan University of Medical Sciences, Gorgan, Iran, were entered in this study. None of the patients were vaccinated for HBV or had benefited from immunoglobulin therapy. All patients had negative results for antibodies against hepatitis $C$, hepatitis D and Human Immunodeficiency Virus (HIV). Blood samples were collected on 5\% EDTA anticoagulant and plasma was separated for further examination.

\subsection{Hepatitis B Virus Infection Marker Detection}

The HBV serological markers (HBsAg and HBeAg) were tested using commercially available enzyme-linked immune sorbent assay (ELISA) kits (DialabGmbH, Wiener Neudorf, Austria).

\subsection{DNA Extraction}

The HBV-DNA was extracted from $200 \mu \mathrm{L}$ of each plasma sample, using QIAamp DNA Mini Kit (Qiagen, Hamburg, Germany) following the manufacturer's instruction and extracted DNA was stored at $-20^{\circ} \mathrm{C}$ for the PCR process.

\subsection{Primer Selection}

Suitable primers were selected to achieve optimum PCR sensitivity and the PC region amplification. The follow- ing primers yielded $390 \mathrm{bp}$ amplification in accordance to nucleotide position 1689 to 2078 (10). $5^{\prime}$ ACCTTGAGGCATACTTCAAA3' (Forward) 1689-1708 5' CAGAATAGCTTGCCTGAGTGC 3' (Reverse) 2058-2078

\subsection{Polymerase Chain Reaction and DNA Amplifi- cation}

The amplification mixture contained 100ng of extracted DNA, $1 \times$ PCR buffer, $1.5 \mathrm{mM} \mathrm{MgCl}$, $0.2 \mathrm{mM}$ dNTP, $2.5 \mathrm{U}$ Taq DNA polymerase (Qiagen, Hamburg, Germany) and 0.4 $\mathrm{pmol} / \mu \mathrm{L}$ of each primer, in a total volume of $50 \mu \mathrm{L}$, with distilled water. The PCR profile was an initial 5 min denaturation at $95^{\circ} \mathrm{C}$, followed by 30 cycles of amplification, including denaturation for 1 minute at $95^{\circ} \mathrm{C}$, primer annealing for 1 minute at $55^{\circ} \mathrm{C}$ and extension for 2 minutes at $72^{\circ} \mathrm{C}$, with a final extension at $72^{\circ} \mathrm{C}$ for 5 minutes. The 390 bp amplification products were analyzed by gel electrophoresis on $1 \%$ agarose gel stained with ethidium bromide to determine HBV-DNA positive and negative samples.

\subsection{DNA Sequencing and Mutation Analysis}

The positive PCR products were sent to Macrogen Inc., Seoul, Korea, for automated sequencing. Then nucleotide sequences were aligned with the standard hepatitis $B$ sequence [Accession number: AB033559] from the GeneBank database, for mutation detection and analysis (11).

\section{Results}

The mean age of the patients was $36.8 \pm 11.5$ years and $74 \%$ of them were male. All of them were HBsAg positive and 100 out of 120 (83.3\%) patients were HBeAg negative. Sex and age specific prevalence of G1896A mutants showed no significant difference between sexes and ages. All isolates belonged to genotype $\mathrm{D}$, subgenotype $\mathrm{D}_{1}$, subtype ayw $\mathrm{w}_{2}$, according to our previous study (9). The comparison of our nucleotide sequences with the reference sequence showed an overall high rate of mutation, and only $0.8 \%$ of patients had no mutations in the PC region. Frame shift mutation was found in eight patients (6.6\%) in the PC region.

\subsection{Point Mutation at Nucleotide 1896 of the Pre- core Region}

The Alignment of Sequenced Samples of Patients with Reference Sequence Using the CLUSTALW Program has been shown in Table. 1 . Among the 78 point mutations in the PC region, 26 (33.3\%) occurred as silent mutations and $52(66.7 \%)$ as missense mutations. Substitutions at position G1896A were seen in 44 (36.66\%), leading to the creation of stop codon in the 28th amino acid of the PC region in 39 (32.50\%) of these patients.

\subsection{Hepatitis B e Antigen Positivity and Basal Core Promoter and Precore Mutations}

Our results showed that G1896A was detected as the 
Zhand Set al.

most prevalent mutation in 44 patients, out of which 41 (93.18\%) were HBeAg negative. One of the samples with G1896A mutation was registered in NCBI under the accession number: KC928094.

\section{Discussion}

Hepatitis B virus continues to be one of the most important viral pathogens in humans. Previous studies have indicated that Iran is considered as an intermediate endemic area of HBV infection (12). The clinical relevance of the G1896A PC mutation in chronic hepatitis B (CHB) is still poorly understood. The G1896A mutation in the PC region has been found to be the most common mutation in chronic HBeAg-negative patients (13). This mutation creates a stop codon that prevents translation of the PC reading frame and terminates the production of HBeAg. However, these patients present constant replication at sufficient levels to continuously damage liver and can progress toward cirrhosis (14). The median prevalence of the 1896 PC mutation in HBeAg-negative adults was reported to be $50 \%$ in Asia, 92\% in the Mediterranean, and $24 \%$ in USA (15).

The frequency of the 1896 PC mutation varies geographically and depends primarily on the genotype of $\operatorname{HBV}(16,17)$. In this study, we did not compare the relationship among different genotypes of HBV and the clinical outcome of liver disease, because all of the patients were infected with genotype D. In agreement with our results, a study from Brazil showed that the G1896A PC mutation occurred in 36\% of Brazilian patients with $\mathrm{CHB}$, of which $58.6 \%$ were $\mathrm{HBeAg}$ negative (18). A higher rate (95.3\%) of the G1896A mutation was also reported in the HBeAg-negative group (19). Triki et al. (20) studied HBeAg-positive and HBeAg-negative Tunisian patients and evidenced the PC stop codon mutation in $86 \%$ of them, a result similar to ours (92.4\%). In relation to the status of HBeAg, the results of Ayed et al.(21) on chronic HBV patients in Tunisia found that a PC stop codon was more commonly found in HBeAg-negative patients with genotype D compared with HBeAg-positive patients (94.5\% vs. $87.8 \%$, respectively). These results were in agreement with published data in the Mediterranean area (19, 22-27).

In Spain, where genotypes A and D are predominant, PC mutants were detected in $65.3 \%$ of HBeAg-negative patients (28). Conversely, a study from China (29), where genotypes $\mathrm{B}$ and $\mathrm{C}$ are predominant, revealed a high prevalence of A1896 mutant. The e antigen is an important target for cell-mediated and antibody-mediated immune responses, and the loss of e antigen production by PC mutants may help the virus to evade the host immune response (30). Therefore, the occurrence of the PC mutation seems to be a strategy of viral selection secondary to the immunological pressure against HBV (16). In contrast with our results, the study from Sweden determined that none of the six genotype $\mathrm{D}$ isolates showed the PC stop codon mutation at nucleotide 1896 during the follow-up of 17 months after anti-HBe seroconversion (31).
Besides the fact that they are evident in studies performed in different geographical regions, these discrepancies are also observable also when carried out in a single country with isolates belonging to different genotypes (21, 28). In another study, in agreement with our report, was undertaken in Spain, where genotypes A and D are predominant, PC mutants were detected in $65.3 \%$ of HBeAgnegative patients (32). This study indicates that the rate of G1896A mutation at the PC region among HBeAg-negative patients in the Golestan province of Iran was similar to the average rate of other parts of Iran. The PC stop codon mutation was detected in $93.18 \%$ of HBeAg-negative patients. Further studies, including epidemiological investigations, with larger sample sizes are necessary to elucidate the exact role of these mutations in the clinical and epidemiological course of chronic HBV infection.

Table 1. The Alignment of Sequenced Samples of Patients (Number 6c, 11c) With Reference Sequence Using the CLUSTALW Program

\begin{tabular}{|c|c|}
\hline & Sequence \\
\hline Ref & $\begin{array}{l}\text {-TGGGGGAGGAG-ATTAGATTAAAGGTCTTTGTACTAGGAG- } \\
\text { GCTGTAGGCATAAATTG-G }\end{array}$ \\
\hline $6 c$ & $\begin{array}{l}\text {-TGGGGGAGGAT-ATTGGATTAATGATTTATGTATTAGGAG- } \\
\text { GCTGTAGGCATAAATCCCG }\end{array}$ \\
\hline 11c & $\begin{array}{l}\text { TTGGGGGAGGAGTGTAGGATTAAGGTTGTTTGTTTTACGAG- } \\
\text { GCTGTAGGCATAATTTG-G }\end{array}$ \\
\hline Ref & $\begin{array}{l}\text { TCTGCGCACCAGCACCATGCAACTTTTTCACCTCTGCCTAAT- } \\
\text { CATCTCTTGTTCATGTCC }\end{array}$ \\
\hline $6 c$ & $\begin{array}{l}\text { TTTGCGCACCAGCACCATGCAACTTTTTCACCTCTGCCTAAT- } \\
\text { CATCTCTTGTTCATGTCC }\end{array}$ \\
\hline 11c & $\begin{array}{l}\text { TGTGCGCACCGGCACCATGTAACTTTTTCACCTCTGCCTAAT- } \\
\text { CATCTCTTGTTCATGTCC }\end{array}$ \\
\hline Ref & $\begin{array}{c}\text { TACTGTTCAAGCCTCCAAGCTGTGCCTTGGGTG- } \\
\text { GCTTTGGGGCATGGACATTGACCCTTA }\end{array}$ \\
\hline $6 c$ & $\begin{array}{l}\text { TACTGTTCAAGCCTCCAAGCTGTGCCTTGGGTGGCTT- } \\
\text { TAGGGCATGGACATTGATCCTTA }\end{array}$ \\
\hline 11c & $\begin{array}{l}\text { TACTGTTCAAGCCTCCAAGCTGTGCCTTGGGTGGCTTTAG- } \\
\text { GACATGGACCTCGATCCTTA }\end{array}$ \\
\hline Ref & $\begin{array}{l}\text { TAAAGAATTTGG-AGCTACT--GTGGAGTTACTCTCGTTTTT- } \\
\text { GCCTTCTGACTTCTTTCC }\end{array}$ \\
\hline $6 c$ & $\begin{array}{l}\text { TAAAGAATTTGG-AGCTACT--GTGGAGTTACTCTCGTTTTT- } \\
\text { GCCTTCTGACTTCTTTCC }\end{array}$ \\
\hline 11c & $\begin{array}{l}\text { TAAAGAATTTGGGAGCTACTTGGTGGAGTTACTCTCGTTTTT- } \\
\text { GCCTGGTGACTTCTTTCC }\end{array}$ \\
\hline Ref & $\begin{array}{l}\text { TTCCGTACGAGATCTTCTAGATACCGCCGCGGCTCTGTATC- } \\
\text { GGGATGCCTTAGAGTCTCC }\end{array}$ \\
\hline $6 c$ & $\begin{array}{l}\text { TTCAGTACGAGATCTTCTAGATACCGCCTCAGCTCTGTTTC- } \\
\text { GGGAAGCCTTAGAGTCTCC }\end{array}$ \\
\hline 11c & $\begin{array}{l}\text { TTCAGTACGAGATCTTCTAGATACCGCCCAAGCTCTGTTTC- } \\
\text { GGGAAGCCTTAGAGTCTCC }\end{array}$ \\
\hline Ref & $\begin{array}{l}\text { TGAGCATTGTTCACCTCACCATACTGCACTCAG- } \\
\text { GCAAGCAATTCTTTGCTGGGGAGAACT }\end{array}$ \\
\hline $6 c$ & $\begin{array}{l}\text { TGAGCATTGTACACCTCACCATACTGCACTCAGGCAAGC- } \\
\text { TATTCT---GGG--- }\end{array}$ \\
\hline 11c & $\begin{array}{l}\text { TGAGCATTGCTCACCTCACCATACTGCACTCAGGCAAGC- } \\
\text { TATTCT---GA--- }\end{array}$ \\
\hline
\end{tabular}




\section{Acknowledgements}

We thank Golestan Research Center of Gastroenterology and Hepatology, Gorgan, Iran, for the continuous encouragement during this study and the Department of Microbiology of Golestan University of Medical Sciences, Gorgan, Iran, for providing valuable blood samples.

\section{Authors' Contributions}

Sareh Zhand: design anddefinitionof intellectual content, literature search, experimental studies, data analysis, statistical analysis, manuscript preparation. Chiman Karami: manuscript preparation, manuscript editing, manuscript review. Ahmad Hosseinzadehadli: manuscript preparation, manuscript editing, manuscript review. Alijan Tabarraei: literature search, experimental studies, manuscript preparation, manuscript editing, manuscript review. Masoud Bazuri: literature search, experimental studies, manuscript preparation, manuscript editing, manuscript review. Abdolvahab Moradi: design, definition of intellectual content, literature search, clinical studies, experimental studies, data acquisition, data analysis, statistical analysis, manuscript preparation, manuscript editing, manuscript review, guarantor.

\section{Funding/Support}

This project was supported by the Golestan Research Center of Gastroenterology and Hepatology, Gorgan, Iran. (Grant No. 9003170116).

\section{References}

1. Guarnieri M, Kim KH, Bang G, Li J, Zhou Y, Tang X, et al. Point mutations upstream of hepatitis B virus core gene affect DNA replication at the step of core protein expression. J Virol. 2006;80(2):587-95.

2. De Castro L, Niel C, Gomes SA. Low frequency of mutations in the core promoter and precore regions of hepatitis B virus in antiHBe positive Brazilian carriers. BMC Microbiol. 2001;1:10.

3. Chan HL, Hussain M, Lok AS. Different hepatitis B virus genotypes are associated with different mutations in the core promoter and precore regions during hepatitis $\mathrm{B}$ e antigen seroconversion. Hepatology. 1999;29(3):976-84.

4. Abbas Z, Muzaffar R, Siddiqui A, Naqvi SA, Rizvi SA. Genetic variability in the precore and core promoter regions of hepatitis $B$ virus strains in Karachi. BMC Gastroenterol. 2006;6:20.

5. Buckwold VE, Xu Z, Chen M, Yen TS, Ou JH. Effects of a naturally occurring mutation in the hepatitis $\mathrm{B}$ virus basal core promoter on precore gene expression and viral replication. J Virol. 1996;70(9):5845-51.

6. Alexopoulou A. Mutants in the precore, core promoter, and core re gions of Hepatitis B virus, and their clinical relevance.; 2009.

7. Alavian SM, Fallahian F, Lankarani KB. The changing epidemiology of viral hepatitis B in Iran. J Gastrointestin Liver Dis. 2007;16(4):403-6.

8. Gholamreza R, Shahryar S, Abbasali K, Hamidreza J, Abdolvahab $\mathrm{M}$, Khodaberdi K, et al. Seroprevalence of hepatitis B virus and its co-infection with hepatitis D virus and hepatitis $C$ virus in Iranian adult population. Indian J Med Sci. 2007;61(5):263-8.

9. Moradi A, Zhand S, Ghaemi A, Javid N, Tabarraei A. Mutations in the $S$ gene region of hepatitis B virus genotype D in Golestan Province-Iran. Virus Genes. 2012;44(3):382-7.

10. Park YM, Kim BS, Tabor E. Precore codon 28 stop mutation in hepatitis B virus from patients with hepatocellular carcinoma. Korean J Intern Med.1997;12(2):201-7.
11. Okamoto H, Tsuda F, Sakugawa H, Sastrosoewignjo RI, Imai M, Miyakawa Y, et al. Typing hepatitis B virus by homology in nucleotide sequence: comparison of surface antigen subtypes. J Gen Virol.1988;69 ( Pt 10):2575-83.

12. Poorolajal J, Majdzadeh R. Prevalence of chronic hepatitis B infection in Iran: a review article.J Res Med Sci. 2009;14(4):249-58.

13. Hadziyannis SJ, Lieberman HM, Karvountzis GG, Shafritz DA Analysis of liver disease, nuclear HBcAg, viral replication, and hepatitis B virus DNA in liver and serum of HBeAg Vs. anti-HBe positive carriers of hepatitis B virus. Hepatology. 1983;3(5):656-62.

14. Lok AS, Hadziyannis SJ, Weller IV, Karvountzis MG, Monjardino J Karayiannis P, et al. Contribution of low level HBV replication to continuing inflammatory activity in patients with anti-HBe positive chronic hepatitis B virus infection. Gut.1984;25(11):1283-7.

15. Funk ML, Rosenberg DM, Lok AS. World-wide epidemiology of HBeAg-negative chronic hepatitis B and associated precore and core promoter variants. J Viral Hepat. 2002;9(1):52-61.

16. Hadziyannis SJ, Vassilopoulos D. Hepatitis B e antigen-negative chronic hepatitis B. Hepatology. 2001;34(4 Pt 1):617-24.

17. Hunt CM, McGill JM, Allen MI, Condreay LD. Clinical relevance of hepatitis B viral mutations. Hepatology. 2000;31(5):1037-44.

18. Rezende RE, Fonseca BA, Ramalho LN, Zucoloto S, Pinho JR, Bertolini DA, et al. The precore mutation is associated with severity of liver damage in Brazilian patients with chronic hepatitis B. JClin Virol. 2005;32(1):53-9.

19. Grandjacques C, Pradat P, Stuyver L, Chevallier M, Chevallier P, Pichoud C, et al. Rapid detection of genotypes and mutations in the pre-core promoter and the pre-core region of hepatitis B virus genome: correlation with viral persistence and disease severity. J Hepatol. 2000;33(3):430-9.

20. Triki H, Ben Slimane S, Ben Mami N, Sakka T, Ben Ammar A, Dellagi K. High circulation of hepatitis B virus (HBV) precore mutants in Tunisia, North Africa. Epidemiol Infect. 2000;125(1):169-74.

21. Ayed K, Gorgi Y, Ayed-Jendoubi S, Aouadi H, Sfar I, Najjar T, et al. Hepatitis B virus genotypes and precore/core-promoter mutations in Tunisian patients with chronic hepatitis B virus infection. J Infect. 2007;54(3):291-7.

22. Yalcin K, Degertekin H, Bahcecioglu IH, Demir A, Aladag M, Yildirim B, et al. Hepatitis B virus genotype D prevails in patients with persistently elevated or normal ALT levels in Turkey. Infection. 2004;32(1):24-9.

23. Kidd-Ljunggren K, Miyakawa Y, Kidd AH. Genetic variability in hepatitis B viruses. J Gen Virol. 2002;83(Pt 6):1267-80.

24. Brunetto MR, Giarin M, Saracco G, Oliveri F, Calvo P, Capra G, et al Hepatitis $B$ virus unable to secrete e antigen and response to interferon in chronic hepatitis B. Gastroenterology. 1993;105(3):845-50.

25. Borchani-Chabchoub I, Gargouri A, Mokdad-Gargouri R. Genotyping of Tunisian hepatitis B virus isolates based on the sequencing of preS2 and S regions. Microbes Infect. 2000;2(6):607-12.

26. Saudy N, Sugauchi F, Tanaka Y, Suzuki S, Aal AA, Zaid MA, et al Genotypes and phylogenetic characterization of hepatitis B and delta viruses in Egypt. J Med Virol. 2003;70(4):529-36.

27. Bozdayi AM, Bozkaya H, Turkyilmaz A, Aslan N, Verdi H, Kence A et al. Polymorphism of precore region of hepatitis B virus DNA among patients with chronic HBV infection in Turkey. Infection. 1999;27(6):357-60.

28. Jardi R, Rodriguez F, Buti M, Costa X, Valdes A, Allende H, et al Mutations in the basic core promoter region of hepatitis B virus. Relationship with precore variants and HBV genotypes in a Spanish population of HBV carriers. J Hepatol. 2004;40(3):507-14.

29. Honda A, Yokosuka O, Ehata T, Tagawa M, Imazeki F, Saisho H. Detection of mutations in the enhancer 2/core promoter region of hepatitis B virus in patients with chronic hepatitis B virus infection: comparison with mutations in precore and core regions in relation to clinical status. J Med Virol. 1999;57(4):337-44.

30. Zuckerman AJ, Zuckerman JN. Molecular epidemiology of hepatitis B virus mutants. J Med Virol. 1999;58(3):193-5.

31. Blackberg J, Kidd-Ljunggren K. Genotypic differences in the hepatitis B virus core promoter and precore sequences during seroconversion from HBeAg to anti-HBe. J Med Virol. 2000;60(2):107-12.

32. Gandhe SS, Chadha MS, Arankalle VA. Hepatitis B virus genotypes and serotypes in western India:lack of clinical significance.JMed Virol. 2003;69(3):324-30. 